\title{
Identification of swine influenza virus epitopes and analysis of multiple specificities expressed by cytotoxic T cell subsets
}

\author{
Lasse E Pedersen*, Solvej $\varnothing$ Breum, Ulla Riber, Lars E Larsen and Gregers Jungersen
}

\begin{abstract}
Background: Major histocompatibility complex (MHC) class I peptide binding and presentation are essential for antigen-specific activation of cytotoxic T lymphocytes (CTLS) and swine MHC class I molecules, also termed swine leukocyte antigens (SLA), thus play a crucial role in the process that leads to elimination of viruses such as swine influenza virus (SWIV). This study describes the identification of SLA-presented peptide epitopes that are targets for a swine CTL response, and further analyses multiple specificities expressed by SwIV activated CTL subsets.
\end{abstract}

Findings: Four SwIV derived peptides were identified as T cell epitopes using fluorescent influenza:SLA tetramers. In addition, multiple CTL specificities were analyzed using peptide sequence substitutions in two of the four epitope candidates analyzed. Interestingly both conserved and substituted peptides were found to stain the $\mathrm{CD} 4^{-} \mathrm{CD} 8^{+} \mathrm{T}$ cell subsets indicating multiple specificities.

Conclusions: This study describes a timely and cost-effective approach for viral epitope identification in livestock animals. Analysis of T cell subsets showed multiple specificities suggesting SLA-bound epitope recognition of different conformations.

Keywords: Swine influenza virus, Major histocompatibility complex, Cytotoxic T cell, Viral epitope

\section{Background}

During the last two centuries influenza virus has constantly challenged animal and human health by seasonal outbreaks, most recently illustrated in the emerging 2009 pandemic H1N1 virus which, according to the World Health Organization (WHO), lead to more than 18.000 human deaths. Swine influenza virus (SwIV) is a common pathogen involved in the porcine respiratory disease complex. Beyond the veterinary implications, influenza infections in pigs also imply an important public health risk due to potential inter-species transmission of new reassortant strains of influenza viruses with pandemic capacity [1-4]. Human influenza virus vaccines are regularly updated with contemporary strains in contrast to commercially SwIV vaccines leading to inadequate protection against antigenic diverse viruses. In order to address new vaccine approaches which, based on common

\footnotetext{
* Correspondence: lasse.eggers@gmail.com

National Veterinary Institute, Technical University of Denmark, Frederiksberg C, Denmark
}

T cell epitopes, are able to provide a broader protection against a range of antigenic different viral strains, it is necessary to identify the peptide epitopes that are targets for a swine cytotoxic T cell response.

The selective binding and presentation of peptides in MHC complexes play a crucial role in the adaptive immune response to infectious diseases and vaccines $[5,6]$. Such peptide:MHC (pMHC) complexes are scanned by circulating $\mathrm{CD} 4^{-} \mathrm{CD} 8^{+}$cytotoxic $\mathrm{T}$ cells (CTLs) of the host immune system, occasionally leading to immune activation if the peptide is of foreign origin representing a potential danger to the host. To date pMHC tetramers have been described in work related to the analysis of mice [7], human [8,9], bovine [10], and porcine [11] immune responses. In pigs, MHC class I molecules are termed swine leukocyte antigens (SLA) and one of the most commonly occurring SLA alleles, the SLA-1*0401 [12], has recently been mapped for its peptide binding preferences [13]. This study illustrates the use of pSLA fluorescent tetramers to identify SwIV derived epitopes. In summary, porcine fluorescent tetramers were generated 
with carefully selected influenza virus peptide ligands to measure immune responses against swine influenza virus after immunization of SLA class I matched pigs with inactivated virus.

\section{Methods}

A total of 20 pigs were used in this study of which 16 expressed the SLA-1*0401 class I molecule. All procedures of animal handling and experimentation were approved by the Danish Animal Experiments Inspectorate. Experimental animals received chemically $\left(\mathrm{C}_{3} \mathrm{H}_{4} \mathrm{O}_{2}\right)$ inactivated swine influenza $A$ virus of different strains given in equal volumes of Freund's Incomplete adjuvant with 4 repeated immunizations at three-week intervals (Table 1). Initially, blood samples were collected from all pigs followed by SLA allele typing using PCR-SSP [14-16]. Candidate SwIV epitopes were selected using in silico predictions for binding by the online available NetMHCpan algorithm [17-19], and combined with previously mapped preferences expressed by SLA-1*0401 [13]. Chosen candidate epitopes were then tested for SLA-1*0401 binding affinity using a previously described immunosorbent assay [20]. pSLA-1*0401 based fluorescent tetramers were produced as described previously [9], and porcine $\mathrm{CD}^{+}$cytotoxic $\mathrm{T}$ cell labeling was analyzed by flow cytometry. $\mathrm{APC}$ - and $\mathrm{BV}_{421}$-fluorochromes were used for labeling tetramers whereas $\mathrm{PE}$-conjugated $\mathrm{mAb}$ against porcine $\mathrm{CD} 8 \alpha$ (clone 762-11, BD Pharmingen) and FITC-conjugated mAb against porcine CD4 (clone 74-12-4, BD Pharmingen) were used for additional cell surface staining.

\section{Results}

Virally derived $\mathrm{T}$ cell epitopes in swine were identified by ex vivo analysis of candidate epitope peptides, based on in silico predictions and in vitro validation. Four influenza virus derived candidate epitope peptides (CTELKLSDY, GTEKLTITY, SSSFSFGGF, YVFVGTSRY) and one synthetically designed reference peptide (ASYGAGAGY) were selected for analysis based on a prediction to be bound by the SLA-1*0401 molecule. All selected peptides had NetMHCpan prediction rank scores of 1.00 or lower meaning that the peptide had a predicted affinity within the 1 percentile best candidates compared to a pool of $1,000.000$ natural peptides (Table 2) [17-19]. Following in vitro testing it was found that all four influenza virus peptides were bound with high affinity by the SLA1*0401 MHC class I molecule, and identified as T cell epitopes by ex vivo flow cytometry analysis using influenza:SLA tetramers. Positive samples were defined by a minimum threshold of 2-fold higher staining percentage compared to the negative background control, as previously set by others [22]. Six of the 16 SLA-matched pigs were found to express activated CTL populations showing specificities against the SwIV peptides post immunization (Table 3). SwIV tetramer staining above the 2-fold threshold ranged between 0.8 and $5.3 \%$ of the total $\mathrm{CD} 4{ }^{-} \mathrm{CD} 8 \alpha^{\text {high }}$ cell population depending on the different epitopes and animals (Table 3 , bold numbers). A specific $\mathrm{T}$ cell subset of $6.5 \%$ of the $\mathrm{CD} 4{ }^{-} \mathrm{CD} 8 \alpha^{\text {high }}$ population stained positive for the GTEKLTITY epitope as compared to the negative background control of 1.2\% (Figure 1). In addition, substitutions were introduced in $50 \%$ of the epitope candidates to examine individual $\mathrm{T}$ cell subsets in regard to the expression of multiple $\mathrm{T}$ cell receptor (TCR) specificities. Interestingly both conserved and substituted epitope candidates were found to stain the $\mathrm{CD} 4^{-} \mathrm{CD} 8 \alpha^{\text {high }} \mathrm{T}$ cell subsets. Staining percentages of epitopes including amino acid substitutions compared to their respective immunization strain are marked by an asterix (Table 3 ).

\section{Discussion and conclusion}

This study describes a timely and cost-effective approach for viral epitope analysis and identification in

Table 1 Influenza peptide epitopes and immunization strains

\begin{tabular}{|c|c|c|c|c|c|c|c|c|}
\hline \multirow[b]{3}{*}{$\begin{array}{l}\text { SwIV } \\
\text { candidate } \\
\text { epitope }\end{array}$} & \multicolumn{3}{|c|}{ SLA tetramer peptide epitopes } & \multicolumn{5}{|c|}{ Immunization strains 1-5 } \\
\hline & \multirow[b]{2}{*}{$\begin{array}{l}\text { Viral protein } \\
\text { of origin }\end{array}$} & \multirow[b]{2}{*}{$\begin{array}{l}\text { AA position* } \\
\text { in virus }\end{array}$} & \multirow[b]{2}{*}{$\begin{array}{l}\text { Nucleotide } \\
\text { position* } \\
\text { in virus }\end{array}$} & \multirow{2}{*}{$\begin{array}{c}1 \\
\text { A/swine/Den } \\
\text { mark/101310- } \\
\text { 1/2011(H1N1pdm09) }\end{array}$} & \multirow{2}{*}{$\begin{array}{c}2 \\
\text { A/swine/ } \\
\text { Denmark/ } \\
\text { 101568-1/2011 } \\
\text { (H1pdmN2†) }\end{array}$} & \multirow{2}{*}{$\begin{array}{c}3 \\
\text { A/swine/ } \\
\text { Denmark/ } \\
19126 / 1993 \\
\text { (H1N1) }\end{array}$} & \multirow{2}{*}{$\begin{array}{c}4 \\
\text { A/swine/ } \\
\text { Denmark/ } \\
\text { 101490-3/2011 } \\
\text { (H1N1) }\end{array}$} & \multirow{2}{*}{$\begin{array}{c}5 \\
\text { A/swine/ } \\
\text { Denmark/1037 } \\
\text { 2/2011(H1N2†) }\end{array}$} \\
\hline & & & & & & & & \\
\hline CTELKLSDY & NP & $44-52$ & $130-156$ & + & + & CTELQLSDY & CTELQLSDY & CTELQLSDY \\
\hline GTEKLTITY & PB2 & 623-531 & 1567-1593 & + & + & + & + & + \\
\hline SSSFSFGGF & PB2 & $320-328$ & $958-984$ & + & + & + & + & + \\
\hline YVFVGTSRY & $\mathrm{HA}$ & $215-223$ & $643-669$ & + & + & YVSVESSKY & YVSVVSSKY & YVSWVSSKY \\
\hline
\end{tabular}

Comparison of influenza virus candidate epitope sequences within the different viral strains used for immunizations. (+) SwIV candidate epitope sequence is $100 \%$ conserved in the viral strain used for immunization. $\left(^{*}\right)$ Amino acid position relative to start codon in virus A/swine/Denmark/12687/2003, ( $\dagger$ ) reassortant swine influenza virus encoding a human-like N2 gene [21]. Amino acids in bold mark substitutions in the sequence within the immunization strain compared to the respective candidate epitopes used for tetramer analysis. 
Table 2 Peptide predictions and affinities

\begin{tabular}{lcc}
\hline Peptide sequence & NetMHCpan prediction rank & SLA-1*0401 affinity $K_{D}(\mathrm{nM})$ \\
\hline CTELKLSDY & 1.00 & 16 \\
GTEKLTITY & 0.80 & 34 \\
SSSFSFGGF & 0.80 & 378 \\
YVFVGTSRY & 0.10 & 325 \\
ASYGAGAGY & 0.05 & 19
\end{tabular}

Peptide sequences selected for affinity analysis based on NetMHCpan prediction ranks and SLA-1*0401 amino acid requirements for binding. The lower the $K_{D}$ value the higher the affinity for binding. Peptides having $K_{D}$ values $<500 \mathrm{nM}$ are considered as intermediate affinity ligands whereas a $K_{D}$ value $<100 \mathrm{nM}$ represents a high affinity binding peptide ligand.

Table 3 Influenza virus tetramer staining

\begin{tabular}{|c|c|c|c|}
\hline $\begin{array}{l}\text { Animal ID/ } \\
\text { SwIV strain }\end{array}$ & $\begin{array}{c}\text { Tetramer } \\
\text { SwIV peptide }\end{array}$ & $\begin{array}{l}\text { Peptide substituted } \\
\text { from immunization } \\
\text { strain }\end{array}$ & $\begin{array}{l}\text { Frequency of tetramer (APC + BV421+) cells } \\
\text { (Tetramer }+ \text { cells subtracted negative control) }\end{array}$ \\
\hline & ASYGAGAGY & Negative control & $0.80(0.00)$ \\
\hline $1 /$ & CTELKLSDY & No & $1.70(\mathbf{0 . 9 0})$ \\
\hline \multirow[t]{4}{*}{1} & GTEKLTITY & No & $1.90(\mathbf{1 . 1 0})$ \\
\hline & SSSFSFGGF & No & $1.70(\mathbf{0 . 9 0})$ \\
\hline & YVFVGTSRY & No & $1.60(\mathbf{0 . 8 0})$ \\
\hline & ASYGAGAGY & Negative control & $0.60(0.00)$ \\
\hline $2 /$ & CTELKLSDY & No & $1.70(\mathbf{1 . 1 0})$ \\
\hline \multirow[t]{5}{*}{3} & GTEKLTITY & No & $1.50(\mathbf{0 . 9 0})$ \\
\hline & SSSFSFGGF & No & $1.40(\mathbf{0 . 8 0})$ \\
\hline & YVFVGTSRY & No & $1.50(\mathbf{0 . 9 0})$ \\
\hline & ASYGAGAGY & Negative control & $1.20(0.00)$ \\
\hline & CTELKLSDY & No & $6.30(\mathbf{5 . 1 0})$ \\
\hline 4/ & GTEKLTITY & No & $6.50(\mathbf{5 . 3 0})$ \\
\hline \multirow[t]{4}{*}{3} & SSSFSFGGF & No & $3.90(\mathbf{2 . 7 0})$ \\
\hline & YVFVGTSRY & No & $5.80(\mathbf{4 . 6 0})$ \\
\hline & ASYGAGAGY & Negative control & $2.60(0.00)$ \\
\hline & CTELKLSDY & Yes & $5.80(\mathbf{3 . 2 0 *})$ \\
\hline $6 /$ & GTEKLTITY & No & $5.80(\mathbf{3 . 2 0})$ \\
\hline \multirow[t]{4}{*}{3} & SSSFSFGGF & No & $4.90(2.30)$ \\
\hline & YVFVGTSRY & Yes & $5.90\left(3.30^{*}\right)$ \\
\hline & ASYGAGAGY & Negative control & $0.90(0.00)$ \\
\hline & CTELKLSDY & Yes & $3.00(\mathbf{2 . 1 0 *})$ \\
\hline $8 /$ & GTEKLTITY & No & $2.40(\mathbf{1 . 5 0})$ \\
\hline \multirow[t]{4}{*}{4} & SSSFSFGGF & No & $1.90(\mathbf{1 . 0 0})$ \\
\hline & YVFVGTSRY & Yes & $2.70(\mathbf{1 . 8 0 *})$ \\
\hline & ASYGAGAGY & Negative control & $1.10(0.00)$ \\
\hline & CTELKLSDY & Yes & $2.80(\mathbf{1 . 7 0 *})$ \\
\hline $16 /$ & GTEKLTITY & No & $2.50(\mathbf{1 . 4 0})$ \\
\hline \multirow[t]{2}{*}{5} & SSSFSFGGF & No & $2.30(\mathbf{1 . 2 0})$ \\
\hline & YVFVGTSRY & Yes & $2.70(\mathbf{1 . 6 0 *})$ \\
\hline
\end{tabular}

Tetramer staining frequencies. Percentile numbers in bold show specific tetramer staining post background subtraction. The relative background staining has been defined for each animal by a negative control tetramer (ASYGAGAGY). Italic percentile numbers indicate non-specific staining. Percentages marked by an asterix $(*)$ indentify positive staining by influenza peptides which are sequence substituted compared to the respective immunization strains. 


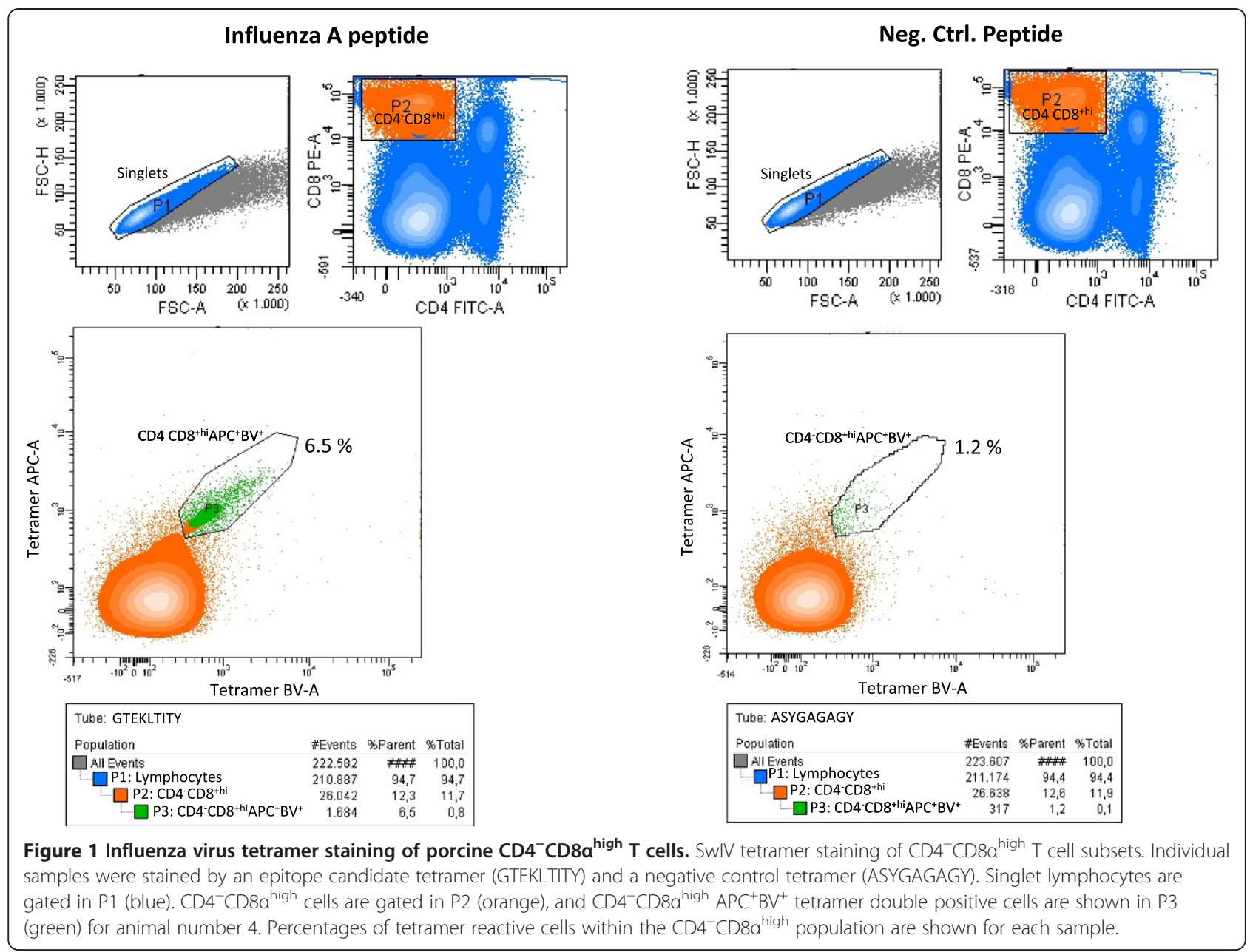

livestock animals. In addition, we hypothesized $\mathrm{CD} 8^{+}$ cytotoxic $\mathrm{T}$ cell subsets to possess multiple specificities. Interestingly, it was found that conserved as well as substituted epitopes positively stained $\mathrm{T}$ cell subsets suggesting SLA-bound epitope recognition of different conformations. These findings correlate with previous studies showing that CTL subsets expressing individual TCRs are capable of recognizing ligands of various conformations presented by the same MHC [23,24].

In conclusion, the data and approaches described have great potential for future studies using the pig as a large animal model for viral epitope identification. Furthermore, by including sequence substituted $\mathrm{MHC}$ ligands in the analysis it was illustrated how $\mathrm{CD} 4^{-} \mathrm{CD}^{+} \mathrm{T}$ cell subsets were capable of expressing multiple $\mathrm{T}$ cell receptor ligand specificities. Finally, identification of T cell epitopes conserved across all types, subtypes and strains of influenza viruses, and including mutations, can be valuable knowledge in terms of future vaccine design as well as in achieving a better understanding of the immune responses elicited by vaccination and natural infection.

\section{Competing interests}

The authors claim no conflict of interest in the publication of this information.

\section{Authors' contributions}

LEP performed the MHC class I low and high resolution typing, the peptide selection and in vitro affinity analyses, the production of SLA tetramers, the cell work and tetramer staining of porcine $\mathrm{CD} 4^{-} \mathrm{CD} 8^{+} \mathrm{T}$ lymphocytes, carried out the data analysis and drafted the manuscript. $\varnothing \varnothing \mathrm{B}$ did the sequencing and sequence alignments of viral strains and peptides used. URI supported the flow cytometry based tetramer staining and data analysis. LEL made substantial contributions to the conception and design of, and was responsible for, animal immunizations and boost. GJU made substantial contributions to the conception and design of the overall study and data analysis. All authors have read and approved the final manuscript.

\section{Funding}

The authors wish to acknowledge the Danish Council for Independent Research, Technology and Production Sciences for partly financial support of the study (274-09-0281).

Received: 17 March 2014 Accepted: 1 September 2014

Published: 6 September 2014

\section{References}

1. Kida H, Ito T, Yasuda J, Shimizu Y, Itakura C, Shortridge KF, Kawaoka Y, Webster RG: Potential for transmission of avian influenza viruses to pigs. J Gen Virol 1994, 75(Pt 9):2183-2188. 
2. Kundin WD: Hong Kong A-2 influenza virus infection among swine during a human epidemic in Taiwan. Nature 1970, 228:857.

3. Torremorell M, Allerson M, Corzo C, Diaz A, Gramer M: Transmission of Influenza A Virus in Pigs. Transbound Emerg Dis 2012.

4. Trebbien R, Larsen LE, Viuff BM: Distribution of sialic acid receptors and influenza A virus of avian and swine origin in experimentally infected pigs. Virol $J$ 2011, 8:434.

5. Horton R, Wilming L, Rand V, Lovering RC, Bruford EA, Khodiyar VK, Lush MJ, Povey S, Talbot CC Jr, Wright MW, Wain HM, Trowsdale J, Ziegler A, Beck S: Gene map of the extended human MHC. Nat Rev Genet 2004, 5:889-899.

6. Kelley J, Walter L, Trowsdale J: Comparative genomics of major histocompatibility complexes. Immunogenetics 2005, 56:683-695.

7. Lemke CD, Graham JB, Lubaroff DM, Salem AK: Development of an MHC class I L(d)-restricted PSA peptide-loaded tetramer for detection of PSA-specific CD8+ T cells in the mouse. Prostate Cancer Prostatic Dis 2011, 14:118-121.

8. Altman JD, Moss PA, Goulder PJ, Barouch DH, Heyzer-Williams MG, Bell Jl, McMichael AJ, Davis MM: Phenotypic analysis of antigen-specific T lymphocytes. Science 1996, 274:94-96.

9. Leisner C, Loeth N, Lamberth K, Justesen S, Sylvester-Hvid C, Schmidt EG Claesson M, Buus S, Stryhn A: One-pot, mix-and-read peptide-MHC tetramers. PLoS One 2008, 3:e1678.

10. Norimine J, Han S, Brown WC: Quantitation of Anaplasma marginale major surface protein (MSP)1a and MSP2 epitope-specific CD4+ T lymphocytes using bovine DRB3*1101 and DRB3*1201 tetramers. Immunogenetics 2006, 58:726-739.

11. Patch JR, Pedersen LE, Toka FN, Moraes M, Grubman MJ, Nielsen M, Jungersen G, Buus S, Golde WT: Induction of foot-and-mouth disease virus-specific cytotoxic T cell killing by vaccination. Clin Vaccine Immunol 2011, 18:280-288.

12. Smith DM, Lunney JK, Martens GW, Ando A, Lee JH, Ho CS, Schook L, Renard C, Chardon P: Nomenclature for factors of the SLA class-I system, 2004. Tissue Antigens 2005, 65:136-149.

13. Pedersen LE, Harndahl M, Rasmussen M, Lamberth K, Golde WT, Lund O, Nielsen M, Buus S: Porcine major histocompatibility complex (MHC) class I molecules and analysis of their peptide-binding specificities. Immunogenetics 2011, 63:821-834.

14. Ho CS, Rochelle ES, Martens GW, Schook LB, Smith DM: Characterization of swine leukocyte antigen polymorphism by sequence-based and PCR-SSP methods in Meishan pigs. Immunogenetics 2006, 58:873-882.

15. Ho CS, Franzo-Romain MH, Lee YJ, Lee JH, Smith DM: Sequence-based characterization of swine leucocyte antigen alleles in commercially available porcine cell lines. Int J Immunogenet 2009, 36:231-234.

16. Ho CS, Lunney JK, Franzo-Romain MH, Martens GW, Lee YJ, Lee JH, Wysocki M, Rowland RR, Smith DM: Molecular characterization of swine leucocyte antigen class I genes in outbred pig populations. Anim Genet 2009, 40:468-478,

17. Hoof I, Peters B, Sidney J, Pedersen LE, Sette A, Lund O, Buus S, Nielsen M: NetMHCpan, a method for MHC class I binding prediction beyond humans. Immunogenetics 2009, 61:1-13.

18. Lundegaard C, Lund O, Nielsen M: Prediction of epitopes using neural network based methods. J Immunol Methods 2011, 374:26-34.

19. Nielsen $M$, Lundegaard $C$, Blicher $T$, Lamberth $K$, Harndahl M, Justesen $S$, Roder G, Peters B, Sette A, Lund O, Buus S: NetMHCpan, a method for quantitative predictions of peptide binding to any HLA-A and -B locus protein of known sequence. PLoS One 2007, 2:e796.

20. Sylvester-Hvid C, Kristensen N, Blicher T, Ferre H, Lauemoller SL, Wolf XA Lamberth K, Nissen MH, Pedersen LO, Buus S: Establishment of a quantitative ELISA capable of determining peptide - MHC class I interaction. Tissue Antigens 2002, 59:251-258.

21. Breum SO, Hjulsager CK, Trebbien R, Larsen LE: Influenza a virus with a human-like n2 gene is circulating in pigs. Genome Announc 2013, 1.
22. Ferrari G, Neal W, Ottinger J, Jones AM, Edwards BH, Goepfert P, Betts MR, Koup RA, Buchbinder S, McElrath MJ, Tartaglia J, Weinhold KJ: Absence of immunodominant anti-Gag p17 (SL9) responses among Gag CTL-positive, HIV-uninfected vaccine recipients expressing the HLA-A*0201 allele. J Immunol 2004, 173:2126-2133.

23. Baker BM, Scott DR, Blevins SJ, Hawse WF: Structural and dynamic control of T-cell receptor specificity, cross-reactivity, and binding mechanism. Immunol Rev 2012, 250:10-31.

24. Frankild S, de Boer RJ, Lund O, Nielsen M, Kesmir C: Amino acid similarity accounts for T cell cross-reactivity and for "holes" in the T cell repertoire. PLoS One 2008, 3:e1831.

doi:10.1186/1743-422X-11-163

Cite this article as: Pedersen et al: Identification of swine influenza virus epitopes and analysis of multiple specificities expressed by cytotoxic T cell subsets. Virology Journal 2014 11:163.

\section{Submit your next manuscript to BioMed Central and take full advantage of:}

- Convenient online submission

- Thorough peer review

- No space constraints or color figure charges

- Immediate publication on acceptance

- Inclusion in PubMed, CAS, Scopus and Google Scholar

- Research which is freely available for redistribution

Submit your manuscript at www.biomedcentral.com/submit
() Biomed Central 